\title{
Effect of dietary soybean meal and multienzyme on intestine histology of beluga sturgeon (Huso huso)
}

\author{
M. Sohrabnezhad • M. Sudagar • M. Mazandarani
}

Received: 27 October 2016/Accepted: 9 August 2017/Published online: 25 September 2017

(C) The Author(s) 2017. This article is an open access publication

\begin{abstract}
This study aimed to evaluate the effect of soybean meal and multienzyme supplementation on intestinal histopathology of beluga sturgeon (Huso huso). Nine diets were formulated (40\% crude protein, $13 \%$ crude fat and $4150 \mathrm{kcal} / \mathrm{kg}$ gross energy) in which fish meal was replaced by soybean meal at 0,40 and $80 \%$ supplemented or not with 1 or $2 \mathrm{~g} / \mathrm{kg}$ of multienzyme Kemin. Fish (initial weight of $820 \mathrm{~g}$ ) were fed on experimental diets four times daily at $1 \%$ body weight for 12 weeks. From histological analyses, intact villus with normal mucosa was found in the FM group, representing the presence of intact epithelium. Supplementation of enzyme at both levels and soybean meal (alone) in the diet resulted in histopathological alterations in the intestine including mild immune cells infiltration, villus blunting, villus fusion, mononuclear immune cells infiltration as well as necrosis. Soybean meal decreased the length of villuses in the proximal and distal intestines $(P<0.05)$. Enzyme was not able to ameliorate the derangements induced by $80 \%$ replacement level of fish meal with soybean meal (treatments SB80E1\% and SB80E2\%). However, coadministrating of the enzyme at both levels with $40 \%$ soybean meal (treatments SB40E1\% and SB40E2\%) was able to inhibit the soybean meal-induced histopathological impairments.
\end{abstract}

Keywords Fish meal $\cdot$ Soybean meal $\cdot$ Multienzyme $\cdot$ Histopathological changes $\cdot$ Intestine $\cdot$ Beluga sturgeon

\section{Introduction}

Due to increasing demand, limitation in global supplies in the near future and the dramatic increase in fish meal (FM) price, efforts to replace FM by plant protein sources as alternatives to FM have been increasing in aqua feeds (Gatlin et al. 2007). Among plant protein sources, defatted soybean meal (SBM) due to its high protein content, relatively well-balanced amino acid profiles and steady supply, has been the most costeffective alternative for FM in diets of many fish species (Lim et al. 2011; Magalhães et al. 2016; Lin and Lou 2011). Several studies have reported that even when heat-treated, standard (solvent-extracted) and full-fat SBM-containing feeds supplemented with limiting amino acids, can lead to decreased growth and energy digestibility in farmed species (Merrifield and Olsen 2011; Krogdahl et al. 2003). However, considerable success in partially or totally replacing FM with SBM in diets for fish species has been achieved (El-Saidy and Gaber 2002; Yaghoubi et al. 2016; Zhou et al. 2011).

It is well demonstrated that different fishes exhibited varied sensitivity to SBM in their diet. In several aquatic species replacement of FM with vegetable protein sources such as SBM resulted in lower weight gain

M. Sohrabnezhad $\cdot$ M. Sudagar $(\bowtie) \cdot$ M. Mazandarani

Department of Fisheries, Gorgan University of Agricultural Sciences and Natural Resource, Gorgan, Iran e-mail: sudagar_m@yahoo.com 
Table 1 Composition and energy of experimental diets

\begin{tabular}{|c|c|c|c|c|c|c|c|c|c|}
\hline & \multicolumn{9}{|c|}{ Dietary treatments } \\
\hline & FM & FME1\% & FME2\% & SB40E0\% & SB40E1\% & SB40E2\% & SB80E0\% & SB80E1\% & SB80E2\% \\
\hline Fish meal & 50 & 50 & 50 & 30 & 30 & 30 & 10 & 10 & 10 \\
\hline Soybean meal & 0 & 0 & 0 & 20 & 20 & 20 & 40 & 40 & 40 \\
\hline Wheat gluten & 2.51 & 2.51 & 2.51 & 12.16 & 12.16 & 12.16 & 22.03 & 22.03 & 22.03 \\
\hline Wheat meal & 24.93 & 24.93 & 24.93 & 15.13 & 15.13 & 15.13 & 3.9 & 3.9 & 3.9 \\
\hline Soybean oil & 4.14 & 4.14 & 4.14 & 4.67 & 4.67 & 4.67 & 5.35 & 5.35 & 5.35 \\
\hline Fish oil & 4.14 & 4.14 & 4.14 & 4.67 & 4.67 & 4.67 & 5.35 & 5.35 & 5.35 \\
\hline Molasses & 3 & 3 & 3 & 3 & 3 & 3 & 3 & 3 & 3 \\
\hline Mineral mix & 2 & 2 & 2 & 2 & 2 & 2 & 2 & 2 & 2 \\
\hline Vitamin mix & 2 & 2 & 2 & 2 & 2 & 2 & 2 & 2 & 2 \\
\hline Dicalcium phosphate & 2 & 2 & 2 & 2 & 2 & 2 & 2 & 2 & 2 \\
\hline Antioxidant & 0.02 & 0.02 & 0.02 & 0.02 & 0.02 & 0.02 & 0.02 & 0.02 & 0.02 \\
\hline Mold inhibitor & 0.25 & 0.25 & 0.25 & 0.25 & 0.25 & 0.25 & 0.25 & 0.25 & 0.25 \\
\hline Filler & 0.91 & 0.91 & 0.91 & 0 & 0 & 0 & 0 & 0 & 0 \\
\hline Binder & 3 & 3 & 3 & 3 & 3 & 3 & 3 & 3 & 3 \\
\hline Methionine & 0.5 & 0.5 & 0.5 & 0.5 & 0.5 & 0.5 & 0.5 & 0.5 & 0.5 \\
\hline Lysin & 0.5 & 0.5 & 0.5 & 0.5 & 0.5 & 0.5 & 0.5 & 0.5 & 0.5 \\
\hline Choline chloride & 0.1 & 0.1 & 0.1 & 0.1 & 0.1 & 0.1 & 0.1 & 0.1 & 0.1 \\
\hline Kemin & 0 & 1 & 2 & 0 & 1 & 2 & 0 & 1 & 2 \\
\hline Crude protein & 40 & 40 & 40 & 40 & 40 & 40 & 40 & 40 & 40 \\
\hline Crude lipid & 13.27 & 13.27 & 13.27 & 13 & 13 & 13 & 13 & 13 & 13 \\
\hline $\begin{array}{l}\text { Gross energy }(\mathrm{Kcal} / \\
\mathrm{Kg})\end{array}$ & 4150 & 4150 & 4150 & 4174 & 4174 & 4174 & 4179 & 4179 & 4179 \\
\hline
\end{tabular}

(Francis et al. 2001) and histopathological damages (Aslaksen et al. 2007; Kraugerud et al. 2007; Krogdahl et al. 2003), the magnitude of which depends on the source and level of replacement (Merrifield and Olsen 2011). Thus, the change from FM to soybean meal generally causes several metabolic and health challenges for the farmed aquatics (Heikkinen et al. 2006). Hence, when using plant derived materials, especially those from soybean at high replacement levels it is necessary to consider the impacts on intestine histology as the gastrointestinal (GI) tract can be one of the important infection routes for some pathogens in fish (Merrifield and Olsen 2011; Gatlin et al. 2007).

There is growing interest to culture beluga sturgeon in Iran due to its large size, fast growth rate and tasty flesh (Ghomi et al. 2011). The aim of the present study was to evaluate the effect of soybean meal and multienzyme supplementation on intestinal histopathology of beluga sturgeon (Huso huso) and whether enzyme supplementation can reduce the negative impact of SBM diet on histopathological changes of beluga intestine.

Fig. 1 Histomorphological features of the proximal intestine of beluga sturgeon fed SBM diet. Cross section from proximal intestine; a FM (fish meal only), b FME1\% (fish meal + 1\% enzyme), c FME2\% (fish meal + 2\% enzyme), d SB40E0\% (40\% soybean meal $+0 \%$ enzyme), e SB40E1\% (40\% soybean meal $+1 \%$ enzyme), f SB40E2\% (40\% soybean meal $+2 \%$ enzyme), f SB80E0\% (80\% soybean meal + 0\% enzyme), g SB80E1\% (80\% soybean meal $+1 \%$ enzyme), h SB80E2\% (80\% soybean meal $+2 \%$ enzyme). See intact villus (IV) with normal mucosa in the control group, which are representing intact epithelium (IE). Intact villus (IV), blunting of villuses (BV), fusion of villus (FV), necrosis in the villuses (N), mild immune cell infiltration in the villus (MIM), mononuclear immune cells (MoIM), severe immune cells infiltration (SIM) morphonuclear immune cells PIM) (H\&E staining, $\times 40, \times 100$ and $\times 400$ magnifications; all images are captured under 2.4 optical zoon provided by camera) 


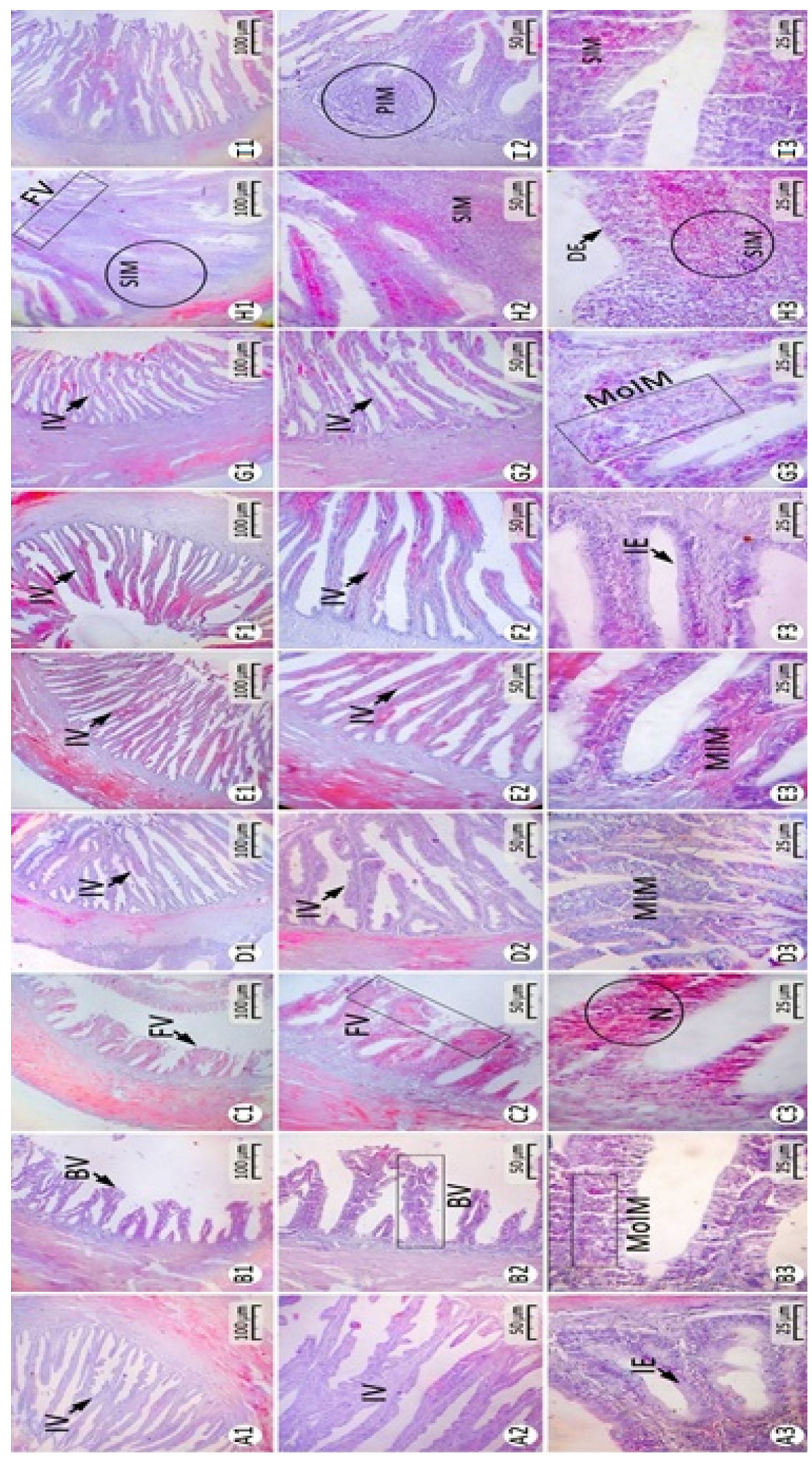


Fig. 2 Histomorphological features of the mid intestine of beluga sturgeon fed SBM diet. Cross section from mid intestine; a FM (fish meal only), b FME1\% (fish meal $+1 \%$ enzyme), c FME2\% (fish meal $+2 \%$ enzyme), d SB40E0\% (40\% soybean meal $+0 \%$ enzyme), e SB40E1\% (40\% soybean meal $+1 \%$ enzyme), f SB40E2\% (40\% soybean meal $+2 \%$ enzyme), f SB80E0\% (80\% soybean meal + 0\% enzyme), g SB80E1\% (80\% soybean meal $+1 \%$ enzyme), h SB80E2\% (80\% soybean meal $+2 \%$ enzyme). Intact villus (IV), blunting of villuses (BV), fusion of villus (FV), necrosis in the villuses (N), mild immune cell infiltration in the villus (MIM), mononuclear immune cells (MoIM), severe immune cells infiltration (SIM) morphonuclear immune cells PIM) (H\&E staining, $\times 40, \times 100$ and $\times 400$ magnifications; all images are captured under 2.4 optical zoon provided by camera)

\section{Materials and methods}

\section{Experimental diets}

Nine experimental diets were formulated to be isonitrogenic ( $40 \%$ crude protein), isofat (13\% crude fat) and isoenergetic ( $4150 \mathrm{kcal} / \mathrm{kg}$ gross energy) in a $3 \times 3$ factorial design in which FM was replaced by SBM at 0 , 40 and $80 \%$ supplemented or not with 1 or $2 \mathrm{~g} / \mathrm{kg}$ of multienzyme Kemin (phytase, lipase, xylanase, endo1,3(4)-beta-glucanase, cellulose, alpha amylase, protease) (Kemzyme-Kemin industries, Belgium). Diet formulation has been performed suing UFFDA software (no. 6). All dietary ingredients were mixed through a commercial food mixer and pelleted using a pellet mill (Garma Electric Co., Amol, Iran) through a $3 \mathrm{~mm}$ die. Pellets were sieved to remove particles and stored at room temperature until use. Experimental diet compositions are indicated in Table 1.

Feeding trials

Ninety fish with initial weight of $820.2 \mathrm{~g}$ were obtained from Saee sturgeon farm (Sari, Iran). The trial was performed in nine fiberglass tanks $(2 \times 1.8 \mathrm{~m})$ of $1.2 \mathrm{~m}^{3}$ water capacity and supplied with a continuous flow of $5 \mathrm{~L} / \mathrm{min}$. Each tank was divided into two parts using a net in longitudinal direction to obtain two replication in the same tank. The same diet/treatment was supplied for each divide tank ( $n=5$ fish per each divided part). Fishes were then acclimatized for 10 days to the experimental conditions and fed with commercial Coppens diet containing $46 \%$ protein and 15\% fat (Coppense Co., The Netherland) twice daily (06:00 and 18:00 h) during this period. After adaptation period, fish were fed on experimental diets by hand four times a day $(06: 00,12: 00,18: 00$ and 24:00 h) at 1\% body weight for 12 weeks. During the trial, water temperature was $17-21{ }^{\circ} \mathrm{C} ; \mathrm{pH}$ was approximately 7.6, dissolved oxygen was above $6.0 \mathrm{mg} / \mathrm{l}$ and photoperiod controlled to 12-h light and 12-h dark.

Sample collection and histological analysis

At the end of the feeding period, two fishes were removed from each divided part of the tank $(n=4$ fish per each tank) and anesthetized using clove powder $(0.3 \mathrm{~g} / \mathrm{l})$ for $3 \mathrm{~min}$ and then killed to remove intestines for histological analysis. During feeding trial, mortality did not occur. The obtained intestines were fixed with $4 \%$ formalin for further histological analysis. Histological measurements were performed according to Gava et al. (2015). Formalin-fixed intestinal samples were sectioned at three different parts (proximal, middle and distal sections) and routinely processed for histology including dehydration in graded ethanol and equilibration in xylene. Previously fixed intestinal samples were paraffin embedded and cut about $6 \mu \mathrm{m}$ thick by rotary microtome (Microm, Germany). The sections $(6 \mu \mathrm{m})$ were stained with haematoxylin and eosin (HE). After that, two glass slides of proximal, middle and distal sections from both fish were prepared and analyzed under light microscope by multiple magnifications $(40 \times, 100 \times$ and $400 \times)$. The scale bar identification and magnification proof was performed using Measure software, version 1.1.0. Images are captured using on-board camera (Zeiss, Cyber-Shot, Japan).

Statistical analysis

All data were subjected to analysis by General Linear Model (GLM) with a $3 \times 3$ factorial design using SPSS 16.0 software package for Windows (SPSS, Illinois, USA). Significantly differences among the means were 


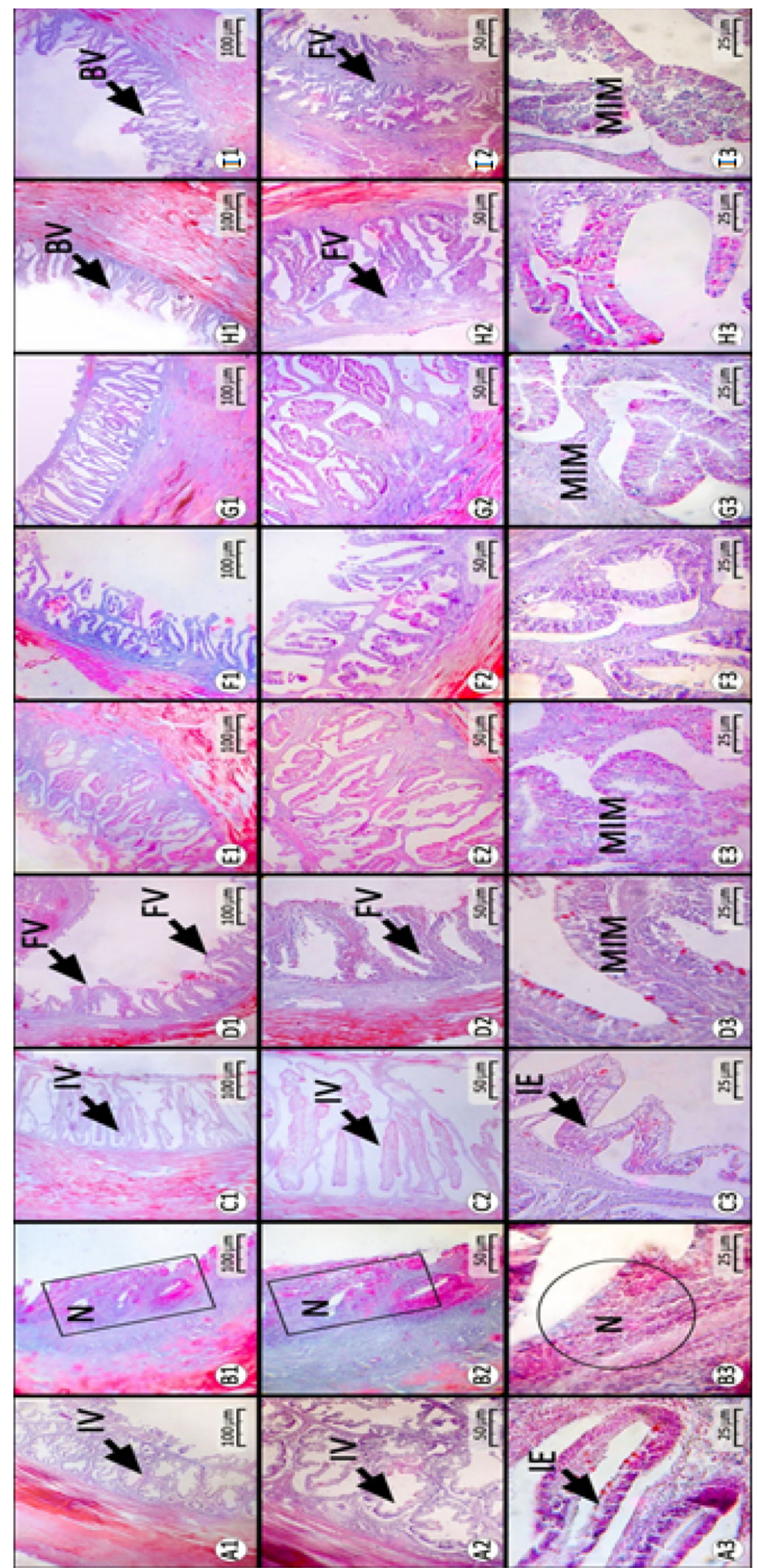


Fig. 3 Histomorphological features of the distal intestine of beluga sturgeon fed SBM diet. Cross section from distal intestine; a FM (fish meal only), b FME1\% (fish meal $+1 \%$ enzyme), c FME2\% (fish meal $+2 \%$ enzyme), d SB40E0\% (40\% soybean meal $+0 \%$ enzyme), e SB40E1\% (40\% soybean meal $+1 \%$ enzyme), f SB40E2\% (40\% soybean meal $+2 \%$ enzyme), f SB80E0\% (80\% soybean meal + 0\% enzyme), g SB80E1\% (80\% soybean meal $+1 \%$ enzyme), h SB80E2\% (80\% soybean meal $+2 \%$ enzyme) (H\&E staining, $\times 40, \times 100$ and $\times 400$ magnifications; all images are captured under 2.4 optical zoom provided by camera)

examined using the Duncan's Multiple Range Test (DMRT) at a 95\% significant difference $(P<0.05)$. All data are presented as Mean $\pm \mathrm{SD}$.

\section{Results}

Histopathological changes in response to types of diets were observed in the proximal part of beluga sturgeon intestine (Fig. 1). Intact villus (IV) with normal mucosa in the treatment 1 (FM) without the addition of soybean meal or multienzyme was found, representing the presence of intact epithelium (IE). Blunting of villuses (BV) in cross section of intestine from treatment 2 (FME1\%) can be seen which is associated with mononuclear immune cells infiltration (MoIM) in higher magnification. The histopathological damages are developed in cross section from group treatment 3 (FME2\%), which is presented with fusion of villus (FV) and sever necrosis in the villuses (N). The cross sections from treatment 4 (SB40) and treatment 5 (SB40E1\%) is representing intact villus (IV), suggesting recovery condition. Mild immune cell infiltration in the villus (MIM) in cross section from treatment SB40 group can be seen similar to that cross section from SB40E1\% group. The severity of damages are increased in cross sections from treatments SB80E0\%, SB80E1\% and SB80E2\% which are representing intensive mononuclear immune cells (MoIM) in treatment SB80E0\% to severe immune cells infiltration (SIM) in treatment SB80E1\% that turned into poly morphonuclear immune cells (PIM) in mucosa of the cross sections from treatment SB80E2\%.

The cross section of mid intestine from control group is representing intact villus, normal mucosa and submucosa layers as well as intact epithelium (Fig. 2). Necrosis (N) in cross section of fish intestine from treatment FME1\% can be observed. Mild immune cells infiltration in cross sections from treatments SB40 and SB40E1\% was occurred, which are enhanced in treatments SB80E0\%, SB80E1\% and SB80E2\%. The cross sections from treatment SB80E1\% and SB80E2\% are representing FV and BV of villus (Fig. 2). Similar histopathological changes induced by soybean meal diet were observed in the distal part of intestine (Fig. 3).

Villus length, widths and mucosal thickness were measured in different parts of beluga intestine (Table 2). In proximal part, the length of villuses in the control was significantly higher than other treatments $(1654 \mu \mathrm{m})$. Fish fed the SB80E0\% diet had the shortest villi length $(401.5 \mu \mathrm{m})(P<0.05)$. Addition of enzyme resulted in higher villus length in treatments SB80E1\% and SB80E2\% (701 and $834 \mu \mathrm{m}$, respectively) $(P<0.05)$. The length of villuses in the mid intestine was shorted than those in the proximal and distal intestines and was not influenced by dietary treatments. Villus length in distal intestine of FM group was similar to that of proximal intestine $(1604.7 \mu \mathrm{m})$. Similar to proximal intestine, enzyme supplementation at both levels decreased the length of villuses in treatments FME1\% and FME2\%.

\section{Discussion}

As reported in several studies, soybean meal is one of the most commonly used protein sources in aqua feeds due to its high protein content and favorable amino acid profile (Merrifield and Olsen 2011). However, even when heat-treated and supplemented with limiting amino acids, full-fat as well as defatted soybean meal rich feeds can lead to decreased growth, lower feed intake and reduced energy and lipid digestibility in fish species. It is known that such effects are mediated by anti-nutritional factors present in soybean meal such as saponins.

Results of the light microscopic analyses in this study showed that supplementation of multienzyme kemin (at both levels) and soybean meal (alone) in the diet of beluga sturgeon resulted in histopathological alterations in the intestine including mild immune cells infiltration, villus blunting, villus fusion, mononuclear immune cells infiltration as well as necrosis segmentally in some villuses. The observed results are in agreement with previous findings on several other fish species fed with soybean meal in their diet. Aslaksen 

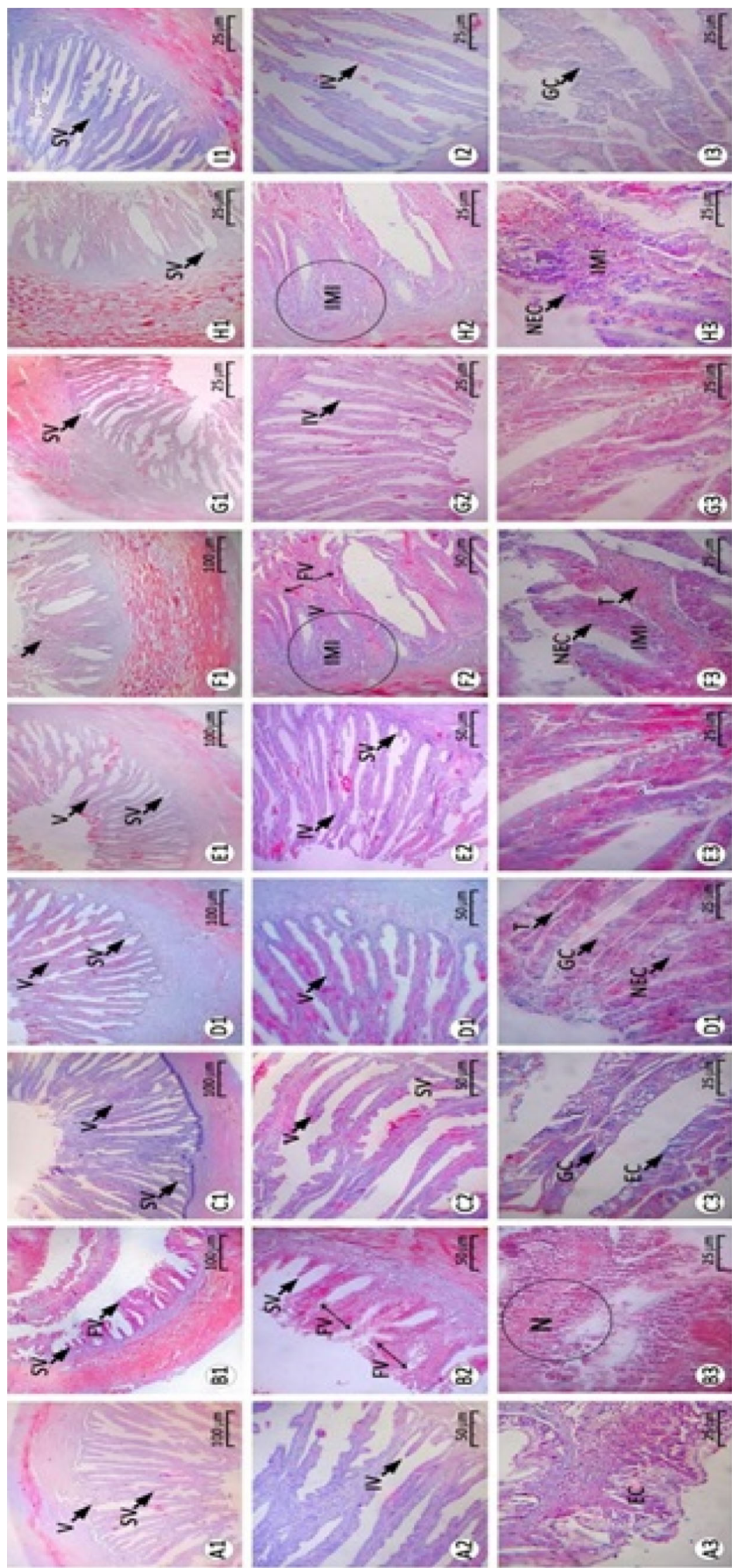


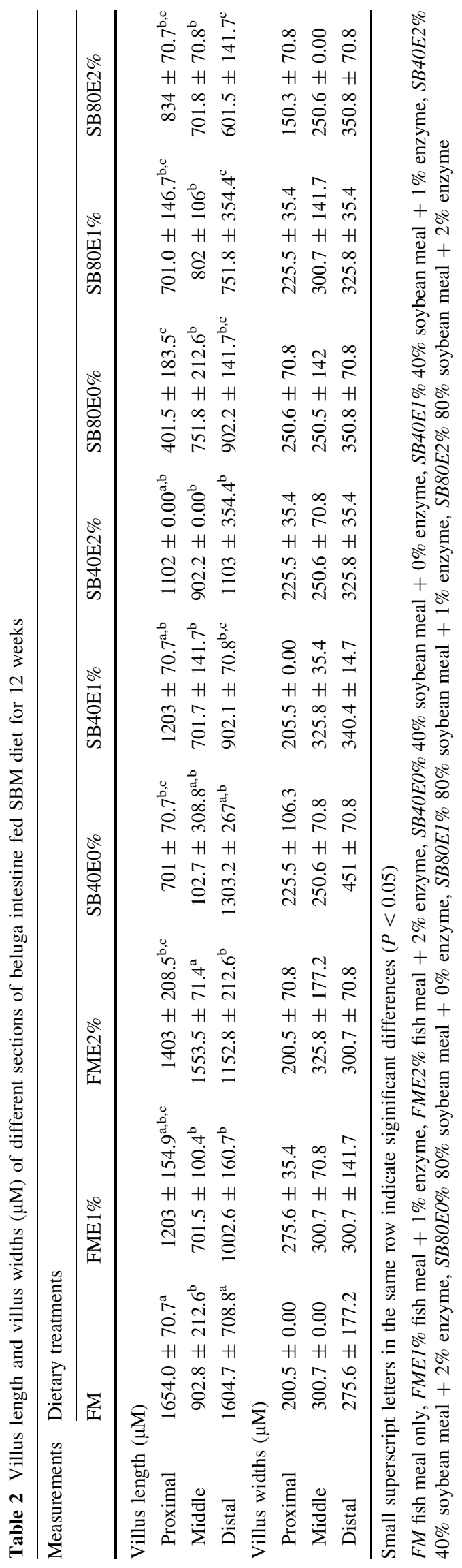


et al. (2007) reported morphological changes in the distal intestine of salmonids caused by dietary inclusion of full-fat as well as solvent-extracted SBM, with and without hulls. These morphological changes (enteritis) have been described as shortening of the simple and complex mucosal folds with a widening of the central stroma (lamina propria) and submucosa, shortened microvilli of the brush border membrane. In their study on Atlantic salmon, Kraugerud et al. (2007) observed morphological changes in the distal intestine of fish fed $10 \%$ dietary defatted soybean meal for 4 weeks. These changes included shortening and fusion of the simple mucosal folds, widening of the lamina propria with increased immune cells infiltration (cellularity), leucocytic cellular infiltration of the submucosa and lamina. Merrifield et al. (2009) observed the effect of replacing 50\% of fish meal with soybean meal on the intestinal epithelium of rainbow trout using electron microscopy. After 16 weeks, soybean meal products caused an inflammatory response in the distal intestine. Fish fed the soybean meal enriched diet displayed missing, damaged, deformed, shorter and thicker microvilli. Additionally, enterocytes appeared to be malformed and irregular. Shorter (distal intestine) and less densely packed (proximal intestine) microvilli on the enterocyte surfaces of fish fed the soybean meal diet than fish fed the fish meal diet was found. These changes could partially explain the effects on growth parameters and feed utilization.

Comparing the damages delivered from enzyme and soybean meal (alone) with each other revealed that soybean meal exerted a higher histopathological changes. However, co-administrating of the multienzyme (at both levels) with $40 \%$ soybean meal (treatments SB40E1\% and SB40E2\%) was able to inhibit the soybean meal-induced histopathological impairments. Moreover, histological analyses exhibited that, enzyme (at both levels) was not able to ameliorate the derangements induced by $80 \%$ replacement level of fish meal with soybean meal (treatments SB80E1\% and SB80E2\%) including polymorphonuclear immune cells infiltration, necrosis, FV and BV in both intestine segments.

In conclusion, results of the present study indicated that beluga was sensitive to dietary soybean meal especially at high inclusion levels. However, co-administrating of the enzyme at both levels with $40 \%$ soybean meal (SB40E1\% and SB40E2\%) was able to inhibit the soybean meal-induced histopathological impairments.

Open Access This article is distributed under the terms of the Creative Commons Attribution 4.0 International License (http:// creativecommons.org/licenses/by/4.0/), which permits unrestricted use, distribution, and reproduction in any medium, provided you give appropriate credit to the original author(s) and the source, provide a link to the Creative Commons license, and indicate if changes were made.

\section{References}

Aslaksen MA, Kraugerud OF, Penn M, Svihus B, Denstadli V, Jørgensen HY, Hillestad M, Krogdahl A, Storebakken T (2007) Screening of nutrient digestibilities and intestinal pathologies in Atlantic salmon, Salmo salar, fed diets with legumes, oilseeds, or cereals. Aquaculture 272:541-555

El-Saidy DMSD, Gaber MMA (2002) Complete replacement of fish meal by soybean meal with dietary L-lysine supplementation for Nile tilapia Oreochromis niloticus (L.) fingerlings. J World Aquac Soc 33:297-306

Francis G, Makkar H, Becker K (2001) Antinutritional factors present in plant derived alternate fish feed ingredients and their effects in fish. Aquaculture 199:197-227

Gatlin DM, Barrows FT, Brown P, Dabrowski K, Gaylord G, Hardy R, Herman E, Hu G, Krogdahl A, Nelson R, Overturf K, Rust M, Sealy W, Skonberg D, Souza EJ, Stone D, Wilson R, Wurtele E (2007) Expanding the utilization of sustainable plant products in aquafeeds: a review. Aquac Res 38:551-579

Gava MS, Moraes LB, Carvalho D, Chitolina GZ, Fallavena LCB, Moraes HLS, Herpich J, Salle CTP (2015) Determining the best sectioning method and intestinal segment for morphometric analysis in broilers. Revista Brasileira de Ciência Avícola. doi:10.1590/1516-635x1702145-150

Ghomi MR, Shahriari R, Langroudi HF, Nikoo M, Von Elert E (2011) Effects of exogenous dietary enzyme on growth, body composition, and fatty acid profiles of cultured great sturgeon Huso huso fingerlings. Aquac Int. doi:10.1007/s10499-0119453-9

Heikkinen J, Vielma J, Kemiläinen O, Tiirola M, Eskelinen P, Kiuru T, Navia-Paldanius D, Wright A (2006) Effects of soybean meal based diet on growth performance, gut histopathology and intestinal microbiota of juvenile rainbow trout (Oncorhynchus mykiss). Aquaculture 261:259-268

Kraugerud OF, Penn M, Storebakken T, Refstie S, Krogdahl A, Svihus B (2007) Nutrient digestibilities, gut function and morphology in Atlantic salmon (Salmo salar) fed diets where non-starch polysaccharides from soy replace cellulose. Aquaculture 273:96-107

Krogdahl A, Bakke-McKellep AM, Baeverfjord G (2003) Effects of graded levels of standard soybean meal on intestinal structure, mucosal enzyme activities, and pancreatic response in Atlantic salmon (Salmo salar L.). Aquac Nutr 9:361-371 
Lim SJ, Kim SS, Ko GY, Song JW, Oh DH, Kim JD, Kim JU, Lee KJ (2011) Fish meal replacement by soybean meal in diets for Tiger puffer, Takifugu rubripes. Aquaculture 313:165-170

Lin S, Lou L (2011) Effects of different levels of soybean meal inclusion in replacement for fish meal on growth, digestive enzymes and transaminase activities in practical diets for juvenile tilapia, Oreochromis niloticus $\times$ O. aureus. Anim Feed Sci Technol 168:80-87

Magalhães R, Lopes T, Martins N, Díaz-Rosales P, Couto A, Pousão-Ferreira P, Oliva-Teles A, Peres H (2016) Carbohydrases supplementation increased nutrient utilization in white seabream (Diplodus sargus) juveniles fed high soybean meal diets. Aquaculture 463:43-50

Merrifield DL, Olsen RE (2011) Dietary effect of soybean (Glycine max) products on gut histology and microbiota of fish. In: ElShemy H (ed) Soybean and nutrition. InTech, Rijeka, Croatia

Merrifield DL, Bradley G, Baker RTM, Dimitroglou A, Davies SJ (2009) Soybean meal alters autochthonous microbial populations, microvilli morphology and compromises intestinal enterocyte integrity of rainbow trout (Oncorhynchus mykiss Walbaum). J Fish Dis 32:755-766

Yaghoubi M, Mozanzadeh MT, Marammazi JG, Safari O, Gisbert E (2016) Dietary replacement of fish meal by soy products (soybean meal and isolated soy protein) in silvery-black porgy juveniles (Sparidentex hasta). Aquaculture 464:50-59

Zhou F, Song W, Shao Q, Peng X, Xiao J, Hua Y, Owari BN (2011) Partial replacement of fish meal by fermented soybean meal in diets for Black Sea bream, Acanthopagrus schlegelii, juveniles. J World Aquac Soc 42:184-197 